\title{
Hypothalamic hamartomas and Gelastic seizures. Chilean experience in a pediatric epilepsy surgery program during 13 years - Review of the literature
}

Paez N Maximiliano ${ }^{1 *}$, Andaur C Karem ${ }^{1}$, Torres S Jorge ${ }^{1}$, Koller C Oswaldo ${ }^{1}$, Goycoolea R Nicolas ${ }^{1}$, Marengo O Juan ${ }^{1}$, Cuadra Lilian ${ }^{2}$ and Valenzuela A Sergio ${ }^{1}$

${ }^{1}$ Pediatric Neurosurgery Department, Dr. Asenjo Neurosurgical Institute, Chile

${ }^{2}$ Chilean National Epilepsy Program and Epilepsy Department, Dr. Asenjo Neurosurgical Institute, Chile

\begin{abstract}
Background: Hypothalamic Hamartomas (HH) are benign tumors with hyperplastic heterotopic tissue growing in a disorganized fashion. They are associated with refractory epilepsy. The typical seizure type is "Gelastic". HH can produce different types of seizures. The epileptogenesis has been discussed focusing in "hamartomacentrism" and "extra hamartoma epileptogenesis".

Objectives: To determine the pre-surgical aspects and surgical techniques with the best outcomes in $\mathrm{HH}$ associated to refractory epilepsy.

Methods: We studied pediatric patients with HH who underwent epilepsy surgery between 2004 and 2017. We analyzed the type of seizures, neurological comorbidity, type of hamartoma in MRI, the electroencephalography records, type of surgery and outcome according to the Engel's and ILAE's classification. We also compare the neuropsychological evaluation before and after surgery.

Results: 7 cases fulfilled inclusion criteria, the ages of starting symptoms vary since 4 months to 7 years old; the mean time of surgery was 5 years. $14 \%$ of cases had Gelastic semiology as the first seizure, $57 \%$ experienced gelastic seizures and $85 \%$ of the cases had at least one generalized seizure. $71.4 \%$ were classified as wide implantation and $28.6 \%$ as pedunculated. $100 \%$ underwent open surgery, through trans-callosal technique in $42.85 \%$ and $57.14 \%$ through trans-silvian surgery. The outcome after surgery, according to Engle classification: 2/7 (28.57\%) resulted with Ia; $2 / 7$ (28.57\%) were Ic; 1/7 (14.28\%) was type II, 1/7 (14.28\%) was type III and $1 / 7(14.28 \%)$ was type IVc.

Conclusions: The possibility to remove the totality of the tumor was $14 \%$. Nonetheless the results evaluated with ILAE's and Engel's outcome score were not bad, possibly because the surgery gets the splitting of the hamartoma from the hypothalamus. The $84 \%$ are classified with improvement after surgery and $42.85 \%$ are currently without seizures. No patient was able to discontinue the AEDs; $57 \%$ required increase the doses and the number of medications.
\end{abstract}

\section{Introduction}

Gelastic seizures (GS) have been well known as part of the hypothalamic hamartoma $(\mathrm{HH})$ syndrome from sessile $\mathrm{HH}$, while endocrinological disturbances [1-3] and or visual impairment may arise from pedunculated $\mathrm{HH}[1,4,5]$. Compulsive burst of laughter is a typical and classical feature of GS [1,6,7]. Drop attacks and other secondary generalized epilepsy symptoms usually develop as the patient ages. Other types of seizure, cognitive deterioration and behavioral problems follow and frequently develop late in the first decade of life $[1,8,9]$.

It has been well known that epileptic discharge originates from the hamartoma itself and propagates to subcortical and cortical areas.

Partial and generalized seizures result along with cognitive/ behavioral problems, including memory deficit and mental retardation $[1,7,10]$.

The exact physiopathology about the epileptogenesis in $\mathrm{HH}$ and the resulted GS is unknown, there are several studies trying to respond this enigma.

In this study we show our experience in the diagnosis and management in $\mathrm{HH}$ associated with refractory epilepsy, emphasizing in the results on GS; as well as we review the available literature about epileptogenesis in $\mathrm{HH}$ and epileptic networks in GS, focusing in the abnormal association among the cells constituting the $\mathrm{HH}$.

\section{Methods}

We analyze the medical records of patients operated in the Pediatric Epilepsy Surgery Program with $\mathrm{HH}$, was collected all the registers between 2004 and 2017. We evaluate different types of variables (some quantitative and other qualitative). Inclusion criteria: 1. Patients under 15 years old, 2. Involved in the epilepsy surgery program for refractory epilepsy, 3. Lesion defined by neuro radiologist as HH, 4. Diagnosed by neuro physician as secondary epilepsy to the HH 6. Presence of Gelastic seizures and other type of seizures, 7. Medical monitoring for at least 2 years after surgery. Exclusion criteria: $\mathrm{HH}$ operated for other reasons

*Correspondence to: Paez N Maximiliano, "Dr. Asenjo" Neurosurgical Institute, Jose Manuel Infante 553, Providencia, Santiago de Chile, Chile, E-mail: neuromar01@gmail.com

Key words: epileptogenesis, gelastic seizures, hypothalamic hamartoma

Received: June 17, 2018; Accepted: July 09, 2018; Published: July 12, 2018 
Maximiliano PN (2018) Hypothalamic hamartomas and Gelastic seizures. Chilean experience in a pediatric epilepsy surgery program during 13 years - Review of the literature

different to epilepsy. (Precocious puberty, mass causing intracranial hypertension).

We obtained 11 cases operated of $\mathrm{HH}, 7$ of them fulfilled all inclusion criteria. The quantitative results were analyzed using range, mean, mode and median. The qualitative founds were analyzed according to the presence or absence of specific topics defined by the authors. In some cases, was necessary to call the patient to get specific data.

\section{Results}

We obtained 7 cases, the ages of starting symptoms vary since 4 months to 7 years old (y.o), average of starting symptoms were 3 years; the mean time of surgery after the diagnostic was 5 years; roughly the patients had 112 seizures per month before surgery. We found 3 patients with more than 30 seizures per month (Table 1).

The first seizure was in the $71 \%$ of cases: focal; $29 \%$ were generalized. Only the $14 \%$ of cases had Gelastic ictal semiology as the first seizure (one case), the maturation of the epileptogenic zone finished yielding secondary generalization in $85 \%$ of cases $(6 / 7)$, only $15 \%$ of the patients remained with focal seizures including gelastic type, However $42 \%(3 / 7)$ had gelastic seizures as part of their epilepsy before surgery (Table 2).

$57 \%$ of the patients experienced gelastic seizures as part of their epilepsy and $85 \%$ of the cases had at least one generalized seizure during their clinic course (Table 3).

The means of antiepileptic drugs taken by the patients were 2 (usually Carbamazepine: CBZ and Valproic Acid: VPA). One of our patients strikingly was allergic for all kind of medications (Table 4).

Other preoperative symptoms or signs different to epilepsy were classified as those with impact on psychomotor development, endocrinological, visual, behavioral and motor signs of focalization.

$57 \%(4 / 7)$ of the patients had normal psychomotor development, $28 \%$ had mental retardation and $15 \%$ had a psychomotor delay achieving finally the goals.

Table 1. Demographic features

\begin{tabular}{|c|c|c|c|}
\hline Case & $\begin{array}{c}\text { Age starting } \\
\text { symptoms }\end{array}$ & $\begin{array}{c}\text { Time since the diagnostic to } \\
\text { the epilepsy surgery }\end{array}$ & $\begin{array}{c}\text { Number of seizures/ } \\
\text { month before surgery }\end{array}$ \\
\hline $\mathbf{1}$ & 2 Years & 11 Years & $30-60$ \\
\hline $\mathbf{2}$ & 7 Years & 1 Year & 6 \\
\hline $\mathbf{3}$ & 3 Years & 10 Months & 15 \\
\hline $\mathbf{4}$ & 1 Year & 9 Years & 15 \\
\hline $\mathbf{5}$ & 6 Months & 11 Years & $>300$ \\
\hline $\mathbf{6}$ & 7 Years & 2 Years & 4 \\
\hline $\mathbf{7}$ & 4 Months & 7 Months & 60 to 750 \\
\hline
\end{tabular}

Table 2. Type of seizures for patient

\begin{tabular}{|c|c|c|}
\hline Case & Type of seizures before surgery & Type of first seizure \\
\hline $\mathbf{1}$ & $\begin{array}{c}\text { Type 1: Right Hemitonic seizures (1-2 per } \\
\text { day, 1 min long) Type 2: Tonic generalized } \\
\text { (1 to 20 min long) until 7 years }\end{array}$ & $\begin{array}{c}\text { Focal motor seizure of right } \\
\text { hemi-body }\end{array}$ \\
\hline $\mathbf{2}$ & Gelastic seizures & Gelastic \\
\hline $\mathbf{3}$ & Generalized & Generalized seizure \\
\hline $\mathbf{4}$ & Focal s. + generalized s. + gelástic s. & $\begin{array}{c}\text { Left hemi-body focal motor } \\
\text { seizure }\end{array}$ \\
\hline $\mathbf{5}$ & Tonic- Clonic Generalized s. & Tonic clonic generalized \\
\hline $\mathbf{6}$ & $\begin{array}{c}\text { Temporal focal seizures and secondary } \\
\text { generalized }\end{array}$ & $\begin{array}{c}\text { Temporal focal seizure } \\
\text { on arms }\end{array}$ \\
\hline $\mathbf{7}$ & $\begin{array}{c}\text { Short inspiration followed by tonic attitude } \\
\text { Short inspiration followed by } \\
\text { tonic attitude on arms }\end{array}$ \\
\hline
\end{tabular}

Table 3. Presence of Gelastic or Generalized seizures in the patients

\begin{tabular}{|c|c|c|}
\hline Case & Gelastic Seizures Yes/ No & Generalized seizures Yes/ No \\
\hline $\mathbf{1}$ & Not & Yes \\
\hline $\mathbf{2}$ & Yes & Not \\
\hline $\mathbf{3}$ & Not & Yes \\
\hline $\mathbf{4}$ & Yes & Yes \\
\hline $\mathbf{5}$ & Yes & Yes \\
\hline $\mathbf{6}$ & Yes & Yes \\
\hline $\mathbf{7}$ & Not & Yes \\
\hline
\end{tabular}

Table 4. Preoperative AED in the studied population

\begin{tabular}{|c|c|}
\hline Case & Antiepileptic drugs before surgery \\
\hline $\mathbf{1}$ & Primidone, CBZ \\
\hline $\mathbf{2}$ & CBZ, VPA \\
\hline $\mathbf{3}$ & CBZ, VPA \\
\hline $\mathbf{4}$ & VPA, FNB, FNT (allergenic reaction for all AED) \\
\hline $\mathbf{5}$ & FNB, CBZ \\
\hline $\mathbf{6}$ & Oxcarbazepine, VPA \\
\hline $\mathbf{7}$ & LEV, VGT \\
\hline
\end{tabular}

$57 \%(4 / 7)$ had concomitant endocrinological symptoms whether associated to precocious puberty as well as hypopituitarism expressed as secondary hypothyroidism. $75 \%$ of the endocrinological disorders were precocious puberty and $25 \%$ was hypopituitarism.

One of the patients (14\%) had bilateral blindness, the rest did not have any visual abnormalities (86\%).

$28.6 \%(2 / 7)$ had behavioral disorders usually aggression and rage, $71.4 \%$ did not have any complaint in this topic.

No one had focal motor symptoms before surgery as a $\mathrm{HH}$ manifestation (Table 5).

About the features of the $\mathrm{HH}$ on images, $71.4 \%$ were classified as width implantation and $28.6 \%$ as pedunculated; $57 \%$ were placed on the intraventricular compartment, 29\% extraventricular and $14 \%$ occupied both spaces. Respect to the side, the proportion was similar between them: $57 \%$ left sided and $43 \%$ right sided. No one enhanced with contrast (Table 6).

Respect to the volume of the $\mathrm{HH}$, we do not have information in two patients. The mean volume of the lesion was $12 \mathrm{ml}$. The range was $25.35 \mathrm{ml}$ and the distribution of the values was not modal (Table 7).

Electrophysiologically, only $14 \%$ had a normal preoperative baseline EEG, $71 \%$ of the patients had a slow rhythm mainly with theta waves and this type of slowness was lateralized to the same side of the lesion, most of them were continuous (80\%) $20 \%$ had a non-continuous theta rhythm. Only $14 \%$ had spikes as an abnormal electrographic finding. The most common ictal finding was spikes associated to slow waves and/or poli spikes (86\%) only in one patient (14\%) there was no found spikes or waves in the surface EEG. The preoperative EEG demonstrated the lobe in $86 \%$, remaining $14 \%$ just showed a hemispheric lateralization. Emphasizing in the lobar distribution: $42 \%$ had electrographic abnormalities in the frontal lobe, $14.2 \%$ in temporal lobe and $28.6 \%$ registered frontotemporal abnormalities. In one patient even in the occipital lobe was found ictal activity. The surface EEG demonstrated left hemisphere lateralization in $42.8 \%$, right side in $14.3 \%$ and bilateral electrographic signs in $42.8 \%$ (Table 8 ).

The surface EEG was concordant with the side of the $\mathrm{HH}$ in the $28.6 \%$, recorded bilateral findings in presence of unilateral $\mathrm{HH}$ in $42.8 \%$; localized the opposite hemisphere in $28.6 \%$. (2/7) With regard to the latter, one of the patients recorded the ictal activity on the left 
Maximiliano PN (2018) Hypothalamic hamartomas and Gelastic seizures. Chilean experience in a pediatric epilepsy surgery program during 13 years - Review of the literature

Table 5. Other symptoms in $\mathrm{HH}$

\begin{tabular}{|c|c|c|c|c|c|}
\hline Case & $\begin{array}{c}\text { Preoperative } \\
\text { Psychomotor } \\
\text { Development }\end{array}$ & $\begin{array}{c}\text { Endocrinological } \\
\text { symptoms before } \\
\text { surgery Yes/Not }\end{array}$ & $\begin{array}{c}\text { Visual } \\
\text { symptoms } \\
\text { before } \\
\text { surgery } \\
\text { Yes/Not }\end{array}$ & $\begin{array}{c}\text { Fehavioral } \\
\text { symptoms }\end{array}$ & $\begin{array}{c}\text { Focal motor } \\
\text { symptoms } \\
\text { before surgery } \\
\text { Yes/no } \\
\text { (Which?) }\end{array}$ \\
\hline $\mathbf{1}$ & $\begin{array}{c}\text { Normal } \\
\text { development until } \\
\text { 2 y.o. Moderate } \\
\text { Mental retardation } \\
\text { at } 12 \text { y.o }\end{array}$ & $\begin{array}{c}\text { Yes (precocious } \\
\text { puberty) }\end{array}$ & Not & No & No \\
\hline $\mathbf{2}$ & $\begin{array}{c}\text { Normal } \\
\text { Yes (precocious } \\
\text { puberty) }\end{array}$ & Not & No & No \\
\hline $\mathbf{3}$ & Normal & Not & Not & Yes & No \\
\hline $\mathbf{4}$ & $\begin{array}{c}\text { Severe Mental } \\
\text { Retardation }\end{array}$ & $\begin{array}{c}\text { Yes } \\
\text { (hypothyroidism) }\end{array}$ & Not & No & No \\
\hline $\mathbf{5}$ & $\begin{array}{c}\text { Psicomotor } \\
\text { Development } \\
\text { delay }\end{array}$ & $\begin{array}{c}\text { Yes (precocious } \\
\text { puberty) }\end{array}$ & $\begin{array}{c}\text { Yes } \\
\text { (Bilateral } \\
\text { blindness) }\end{array}$ & No & No \\
\hline $\mathbf{6}$ & Normal & Not & Not & Yes & No \\
\hline $\mathbf{7}$ & Normal & Not & Not & No & No \\
\hline
\end{tabular}

Table 6. HH and imaging findings

\begin{tabular}{|c|c|c|c|c|}
\hline Case & $\begin{array}{c}\text { Imaging feature (sessile/ } \\
\text { pedunculated/width } \\
\text { implantation) }\end{array}$ & $\begin{array}{c}\text { Intraventricular/ } \\
\text { Extraventricula/ } \\
\text { Both (position } \\
\text { respect the third } \\
\text { ventricle) }\end{array}$ & $\begin{array}{c}\text { Right/Left } \\
\text { hypothalamus }\end{array}$ & $\begin{array}{c}\text { Contrast } \\
\text { enhacement } \\
\text { Yes/Not }\end{array}$ \\
\hline $\mathbf{1}$ & Wide implantation & Intraventricular & Left & No \\
\hline $\mathbf{2}$ & Wide implantation & Intraventricular & Left & No \\
\hline $\mathbf{3}$ & Wide implantation & Intraventricular & Right & No \\
\hline $\mathbf{4}$ & Pedunculated & Both & Rigth & No \\
\hline $\mathbf{5}$ & Wide implantation & Extraventricular & Right & No \\
\hline $\mathbf{6}$ & Pedunculated & Intraventricular & Left & No \\
\hline $\mathbf{7}$ & Wide implantation & Extraventricular & left & No \\
\hline
\end{tabular}

Table 7. Size and volume of the HH

\begin{tabular}{|c|c|c|}
\hline Case & Size (width $\times$ length $\times$ height) $\mathbf{~ m m}$ & Volume of the $\mathbf{H H}(\mathbf{m l})$ \\
\hline $\mathbf{1}$ & $15 \times 11 \times 10$ & 1.65 \\
\hline $\mathbf{2}$ & No information & No information \\
\hline $\mathbf{3}$ & $25 \times 15 \times 20$ & 7.5 \\
\hline $\mathbf{4}$ & No information & No information \\
\hline $\mathbf{5}$ & $45 \times 20 \times 30$ & 27 \\
\hline $\mathbf{6}$ & $18 \times 10 \times 13$ & 2.34 \\
\hline $\mathbf{7}$ & $34,5 \times 16,63 \times 41,04$ & 22 \\
\hline
\end{tabular}

hemisphere being the lesion right sided, but the $\mathrm{HH}$ in this case had intra and extra ventricular compromise and in the second one, the EEG showed ictal activity in the right hemisphere and the $\mathrm{HH}$ was in the left, but the electrographic sign was hemispheric, not lobar (Figure 1).

About the surgical approach: 100\% underwent open surgery, through transcallosal technique in $42.85 \%$ and $57.14 \%$ through transsilvian surgery. Only, a patient received radiosurgery. The $85.71 \%$ had partial resection. One patient had total resection by trans-silvian approach. Respect to the collateral effects after surgery $42.85 \%$ did not have any complication, $57.14 \%$ rest, had some kind of adverse neurological deficits post-operative, the most common was the third nerve palsy being the $100 \%$ of the patients with complications. One patient suffered a subdural effusion requiring subdural peritoneal shunt, another one had wound infection and $14.28 \%$ complained Weber's Syndrome and Diabetes insipidus. The pediatric ICU stay oscillates between 1 to 3 days (mean: 2.14 days, mode: 2, median: 2, range 2 days) (Table 9).
With respect to the outcome after epilepsy surgery in children with $\mathrm{HH}$ in our institution, according to Engle's classification: 2/7 (28.57\%) resulted with Ia; $2 / 7$ (28.57\%) were Ic; $1 / 7$ (14.28\%) was type II, $1 / 7$ (14.28\%) was type III and $1 / 7(14.28 \%)$ was type IVc. Summarizing $71.42 \%$ had improvement after surgery (condition I, II and III) and only $14.28 \%$ worsened. Using the ILAE's classification $3 / 7$ (42.85\%) were class $1,1 / 7(14.28 \%)$ was class $2,1 / 7(14,28 \%)$ was class $3,1 / 7(14,28 \%)$ was class 4 and 1/7 (14,28\%) was class 6 (Figures 2-4) (Table 10).

In the postoperative condition, only the patients with Engle's outcome more than II were performed a control EEG, one of them was demonstrated the presence of right fronto parietal ictal and interictal epileptiform discharges and another one showed generalized spiking.

\section{Association of EEG findings vs $\mathrm{HH}$ sided by imaging}

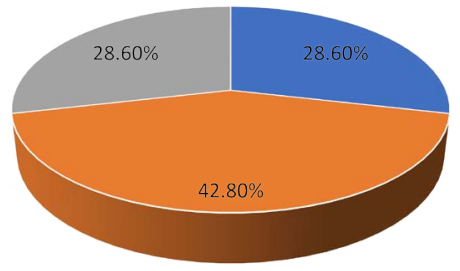

- Concordant findings = Bilateral findings = Wrong

Figure 1. Association of EEG findings vs. HH sided by imaging

\section{Results according to ILAE's Classification}

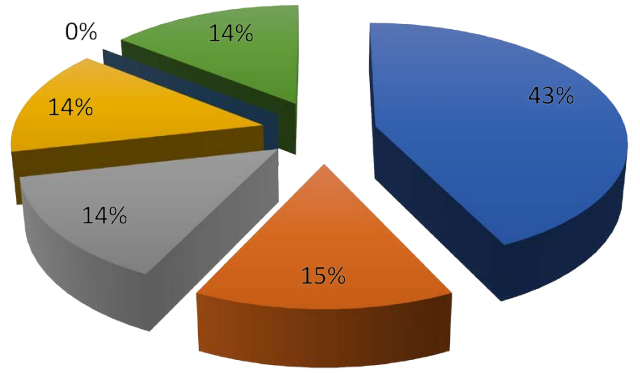

- Class 1

Class 2

Class 3

- Class 4

Class 5

Class 6

Figure 2. Distribution of the results according to ILAE's classification

\section{Results according to Engel's Classification}

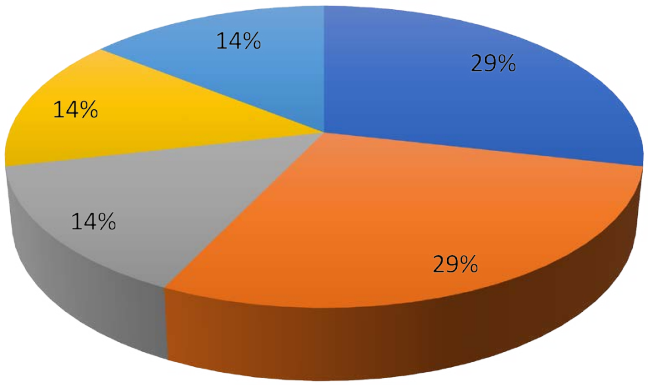

Engel la

Engel ic

Engel II

Engel III

EngelIV

Figure 3. Distribution of the results according to Engel's classification 
Maximiliano PN (2018) Hypothalamic hamartomas and Gelastic seizures. Chilean experience in a pediatric epilepsy surgery program during 13 years - Review of the literature

Table 8. Electrophysiological findings

\begin{tabular}{|c|c|c|c|c|}
\hline Case & Preoperative Baseline EEG & Preoperative Ictal electrophysiological findings & Preoperative EEG Lobar side & $\begin{array}{c}\text { Preoperative EEG } \\
\text { lateralization }\end{array}$ \\
\hline 1 & $\begin{array}{l}\text { Bilateral Theta and delta waves } \\
\text { predominantly on left hemisphere }\end{array}$ & $\begin{array}{l}\text { Bilateral and multifocal Spike and slow wave of high to } \\
\text { middle voltage, more in left hemisphere and in anterior } \\
\text { compartment, with periods of cortical inhibition }\end{array}$ & Frontotemporal & Left \\
\hline 2 & $\begin{array}{l}\text { Asymmetric slowdown, } \\
\text { predominantly on Fp1 and F3 }\end{array}$ & F3-F7 Spike and polispike, F4 spread & Frontotemporal & Left \\
\hline 3 & $\begin{array}{c}\text { Bilateral spikes predominantly in left } \\
\text { frontal lobe }\end{array}$ & Bihemispheric epileptiform spiking activity & Frontal & Bilateral \\
\hline 4 & $\begin{array}{l}\text { Non continuous theta polimorphic } \\
\text { rhythm }\end{array}$ & Sincronic spikes & Temporal & Left \\
\hline 5 & $\begin{array}{l}\text { Diffuse slow signs and bilateral } \\
\text { irritative electrography, more in } \\
\text { bifrontal areas }\end{array}$ & Spike with or without slow wave & Frontal & Bilateral \\
\hline 6 & Normal & Spike -slow wave & Occipital (1999) Frontal (2000) & Bilateral \\
\hline 7 & $\begin{array}{l}\text { Diffuse slowdown. Less voltage in } \\
\text { right hemisphere }\end{array}$ & No epileptiform activity & Hemispheric & Right \\
\hline
\end{tabular}

Table 9. Surgical treatment in $\mathrm{HH}$

\begin{tabular}{|c|c|c|c|c|c|}
\hline Case & Approach & Open surgery & $\begin{array}{c}\text { Radio } \\
\text { neurosurgery }\end{array}$ & $\begin{array}{c}\text { Type of surgery } \\
\text { Intraoperative side effects }\end{array}$ \\
\hline $\mathbf{1}$ & Transcallosal & Yes & Yes & Parcial Resection & Not \\
\hline $\mathbf{2}$ & Transilvian & Yes & No & Parcial Resection & Partial third nerve palsy \\
\hline $\mathbf{3}$ & Transcallosal & Yes & No & Parcial Resection & Not \\
\hline $\mathbf{4}$ & Transilvian & Yes & No & Parcial Resection & $\begin{array}{c}\text { Right third palsy nerve and left hemiparesis. Diabetes } \\
\text { Insipidus. Hydrocephalus (VPS implanted 1 month } \\
\text { postoperative) }\end{array}$ \\
\hline $\mathbf{5}$ & Transcallosal & Yes & No & Parcial Resection & Not \\
\hline $\mathbf{6}$ & Transilvian & Yes & No & Parcial Resection & Wound infection and third nerve palsy \\
\hline $\mathbf{7}$ & Transilvian & Yes & No & Total Resection & Third nerve palsy, subdural effusion requiring a SPS \\
\hline
\end{tabular}

Table 10. Postoperative results about seizure control using Engel and ILAE outcome scale and postoperative seizure whether present

\begin{tabular}{|c|c|c|c|}
\hline Case & Postoperative Engel classification & ILAE outcome scale & Type of postoperative seizures \\
\hline $\mathbf{1}$ & Ic & Class 1 & Gelastic, Temporal focal seizures \\
\hline $\mathbf{2}$ & IVc (3-4 seizures per day) & Class 6 & Gelastic, thrice per day (last evaluation 2011) \\
\hline $\mathbf{3}$ & II & Class 3 & No seizures just auras \\
\hline $\mathbf{4}$ & Ic & Class 2 & Gelastic + generalized \\
\hline $\mathbf{5}$ & IIIc & Class 4 & No seizures \\
\hline $\mathbf{6}$ & Ia & Class 1 & No seizures \\
\hline $\mathbf{7}$ & Ia & Class 1 & \\
\hline
\end{tabular}

\section{Summarizing results using Engel's Classification}

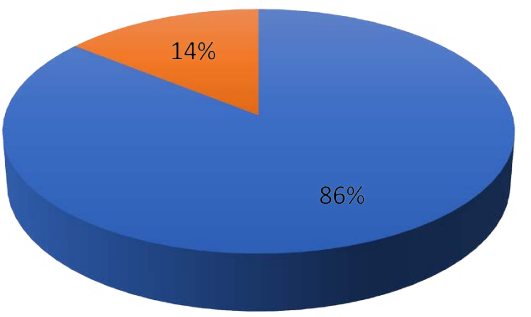

Engel demonstrating improvement

Engel worsened

Figure 4. Summarizing results using Engel's classification

Analyzing the postoperative medication and with a follow up of only two years and comparing between the number of antiepileptic drugs before and after surgery, we found that $1 / 7(14.28 \%)$ has maintained the same number of AEDs after surgery, $2 / 7(28.57 \% \%)$ was possible the reduction from 3 to 1 AED and 4/7 (57.14\%) required more AEDs postoperative respect before surgery (Figures 5 and 6) (Table 11).

Comparing the neuropsychological development pre and postsurgery, the most of patients remained in the same cognitive condition, only in the patient number 2 was observed some calculation difficulty and in the patient 3 was necessary language therapies after surgery. In one patient the mental development was normal before surgery and in the postoperative suffered intracranial sinus thrombosis. An involution in the mental progression was observed but we cannot assume that the regression occurred for the surgery or for the sinus thrombosis (Table 12).

Below we will present a review of the $\mathrm{HH}$ focusing in its epileptogenesis

\section{Hypothalamic hamartomas}

This rare non-neoplastic abnormal mixture of neuronal and glial tissue of the inferior hypothalamus has been postulated to be derived from the mammilo-thalami-cingulate tract, from which $\mathrm{HH}$ is networking other brain areas associated with GS or the pathway from the $\mathrm{HH}$ to the brainstem and cerebellum $[1,11,12]$.

Using a recent electroencephalography-functional MRI (EEGfMRI) studies revealed that the ipsilateral hypothalamus is associated with activation of brainstem tegmentum and contralateral cerebellum; in contrast the cunei, bilateral thalami, caudate nuclei, hippoccampi, 


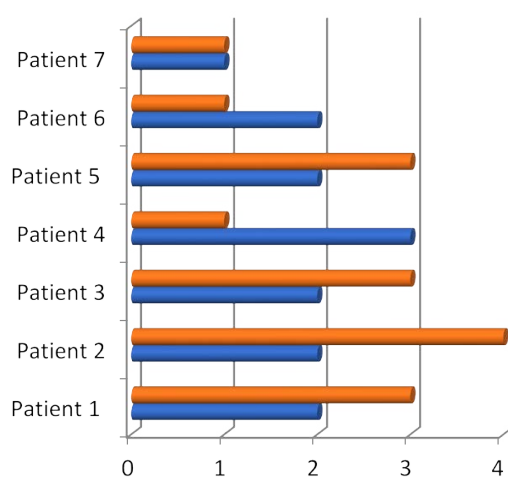

Postoperative Medication

Preoperative Medication

Figure 5. Comparison between preoperative and postoperative medication

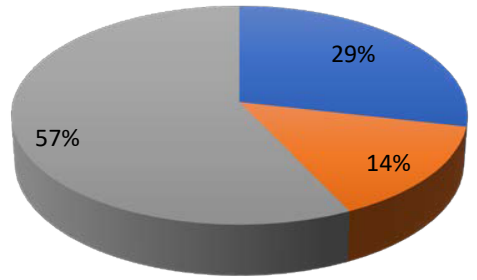

Decreased number of AEDs after Surgery

- Same number of AEDs after surgery

Increased number of AEDs after Surgery

Figure 6. Proportion among the patients who required increase of medication respect to those who were able to decrease it or remain with the same AED

Table 11. Postoperative EEG findings and AED intake

\begin{tabular}{|c|c|c|}
\hline Case & EEG postoperative & Postoperative AED \\
\hline $\mathbf{1}$ & No controlled by EEG & CMZ, VPA, clobazam \\
\hline $\mathbf{2}$ & $\begin{array}{c}\text { Right fronto parietal ictal and interictal } \\
\text { epileptiform discharges (2016) }\end{array}$ & LEV, VPA, clonazepam, lacosamida \\
\hline $\mathbf{3}$ & No controlled by EEG & VPA, oxcarbacepine, clonazepam \\
\hline $\mathbf{4}$ & No controlled by EEG & CBZ \\
\hline $\mathbf{5}$ & Generalized sipiking & CBZ,VPA,Clonazepam \\
\hline $\mathbf{6}$ & Normal & CBZ \\
\hline $\mathbf{7}$ & No controlled by EEG & LEV \\
\hline
\end{tabular}

Table 12. Postoperative Neuropsychological development

\begin{tabular}{|c|c|c|}
\hline Case & $\begin{array}{c}\text { Post-operative Neuropsychological } \\
\text { Development }\end{array}$ & Observations \\
\hline 1 & Moderate Mental retardation & \\
\hline 2 & Specific calculate dificulty & \\
\hline 3 & $\begin{array}{c}\text { Normal, the patient is receiving language } \\
\text { therapies }\end{array}$ & Candidate for radioneurosurgery \\
\hline 4 & Severe Mental Retardation & \\
\hline 5 & Moderate Mental retardation & Patient with Saethre Chotzen syndrome \\
\hline 6 & No information & \\
\hline 7 & Psicomotor Development delay & $\begin{array}{l}\text { Nasal Encefalocele, Intracranial sinus } \\
\text { thrombosis }\end{array}$ \\
\hline
\end{tabular}

paracentral gyri and default mode network (precunei and inferior lateral parietal lobes) are deactivated $[1,13]$.

This activated-deactivated networks result in epileptic discharges through the premotor and frontal opercular areas (voluntary system), which are located on the same side of the broader attachment $[1,14]$ of the $\mathrm{HH}$ on the hypothalamus, as well as the ipsilateral thalamus is activated, mainly $\mathrm{V}_{\mathrm{A}}$ nucleus with the cingulate gyri and the limbic circuit is activated too leading to DM activation (dorso medial thalamic nucleus) with the subsequent "on" activity of orbitofrontal cortex, mesial part of the premotor area and parietal lobe [15] (Figure 7).
This system conveys discharges through the motor cortex, and pyramidal tract to the brainstem $[1,14,16]$.

Intra lesional (inside $\mathrm{HH}$ ) recordings have revealed that the internal epileptiform discharges mix with low voltage activities [1,10,17-19]. Most epileptiform discharges arise from the broad attachment side $[1,18,19]$.

$\mathrm{HH}$ tissue consists of two types of neurons [1,20-23]:

- Small (90\% of all HH neurons) $\rightarrow$ express glutamic acid decarboxylase $\rightarrow$ deliver GABA

- Large ( $10 \%$ of all HH Neurons) $\rightarrow \gamma$-aminobutyric acid responsive neurons

Platinum micro wire intraoperative recordings of single neuron activity captured 10-20 spikes/sc in over $200 \mathrm{HH}$ neurons, producing synchronous firing due to fast firing neurons [1,24]. Therefore, concomitant scalp EEG and depth electrode recording inside HHs may be very useful in disconnecting this lesion from intractable epilepsy. The depth electrode will guide the disconnection surgery as well as confirm the successful disconnection $[1,18,25]$.

Based on their shape and relationship to the hypothalamus, there are several classifications of HHs, and the symptoms and severity depend on their dimensions (size, localization, type of attachment, degree of hypothalamic displacement) (Table 13) [1,5,26,27].

\section{Gelastic seizures in patients with $\mathrm{HH}$}

The $\mathrm{HH}$ is a developmental malformation that occurs in the region of the tuber cinereum and inferior hypothalamus. The epileptic syndrome in $\mathrm{HH}$ patients is characterized by laughing (gelastic) seizures beginning in early infancy [27-29]. They are usually refractory to medical treatment, even to ketogenic diet and vagus nerve stimulation $[1,3,30]$

Although the $\mathrm{HH}$ is a benign tumor and the accompanying gelastic seizures often present during the neonatal period, patients later develop
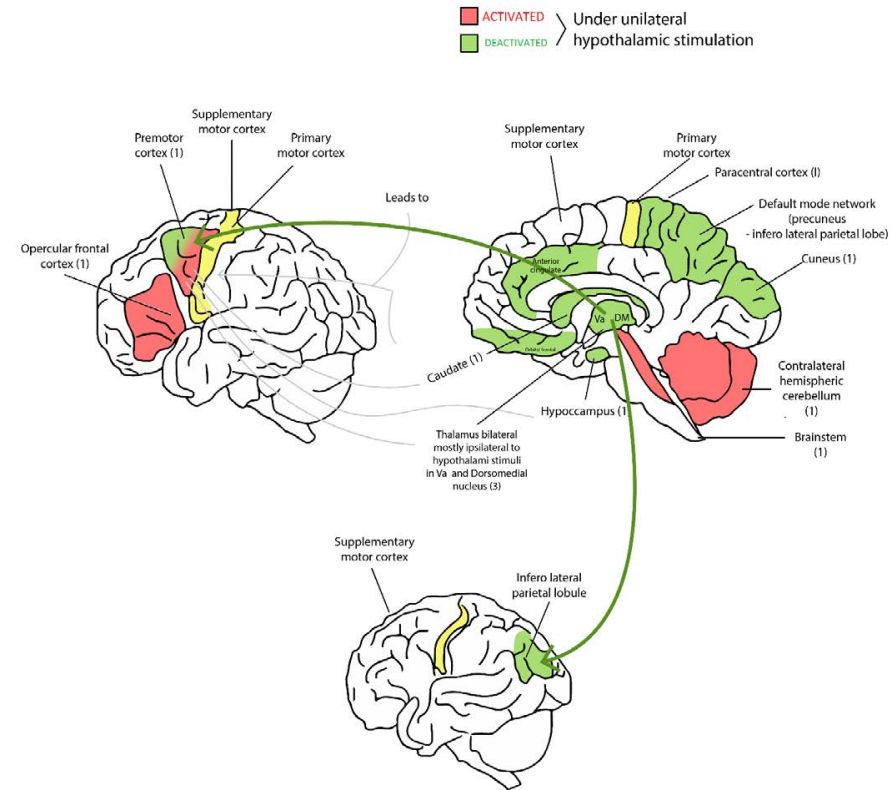

Figure 7. Scheme that represents the activation and deactivation brain areas after discharge initiated into the hypothalamus, in red are depicted the areas with positive input and in green those with negative input. The premotor cortex has both type of stimulus 
Maximiliano PN (2018) Hypothalamic hamartomas and Gelastic seizures. Chilean experience in a pediatric epilepsy surgery program during 13 years - Review of the literature

Table 13. Type of Hypothalamic Hamartomas according to implantation

\begin{tabular}{|c|c|}
\hline Sessile type & $\begin{array}{c}\text { Epilepsy } \\
\text { Behavioral disturbances } \\
\text { Hormonal problems }\end{array}$ \\
\hline Pedunculated & Precocious puberty $[1,5,26,27]$ \\
\hline
\end{tabular}

additional seizure types $[8,28,29]$.

The most effective treatment for epilepsy associated with $\mathrm{HH}$ is surgical resection of the lesion $[28,8,31]$.

Gelastic seizures associated with $\mathrm{HH}$ represent the most common disease model of human subcortical epilepsy. These are originated from the "voluntary system" from premotor and frontal opercular areas. Since ictal laughter associated with $\mathrm{HH}$ appears mechanical and unnatural $[16,28,29]$ and usually does not result in feeling positive emotions $[10,28,32,33]$.

Initiated by abnormal electrical activity spreading rostrally and dorsally to the areas in the neighboring limbic system, and caudally to the brainstem, the $\mathrm{HH}$ can induce physiological and psychophysiological manifestations of laugh attacks $[28,34]$.

\section{Neuropathology of $\mathbf{H H}$}

As was said before, small round soma and bipolar or unipolar morphology with largely unbranched and aspiny dendrites [20$22,28]$ are approximately $90 \%$ of total neuron population. These express glutamic acid decarboxilase (GAD) hence, these neurons are GABAergic interneurons with local network connections [23,28,35] (Figure 8).

Large neurons make up approximately $10 \%$ of total neuron population in $\mathrm{HH}$ tissue and are dispersed throughout the tissue, although often situated at the edges of the small neuron cluster $[20,21,28]$. These cells have features consistent with projection-type neurons, including pyramidal morphology, abundant Nissl substance, and multiple processes, often with a single large proximal dendrite [222,28]. Dendrites are more likely to be branched and spiny. At least some $\mathrm{HH}$ large neurons express markers consistent with excitatory neurotransmitters, such as Vglut2.

\section{Epileptogenesis of human gelastic seizures}

The mechanisms underlying the epileptogenesis of gelastic seizures are unknown, the hypothesis available are:

\section{Local irritation of adjacent normal structures}

Especially large size tumors mechanically affect and distort local anatomy, altering the excitability of hypothalamic networks.

Anatomical analysis showed that $\mathrm{HH}$ lesions within the third ventricle are often associated with gelastic seizures $[4,5,27,28,36]$ and larger lesions have the features of symptomatic generalized epilepsy [28,37].

However, the presence of epilepsy in patients with $\mathrm{HH}$ appears to correlate with the region of lesion attachment (posterior hypothalamus in the region of the mammillary body) rather than lesion size [28,38-40].

\section{Abnormalities of hormone expression}

$\mathrm{HH}$ cells express neuropeptides, which may contribute with seizures in other conditions $[23,28,41]$. Hormones secreted by the hypothalamus and pituitary have been identified during gelastic seizures $[3,28]$.

\section{3. $\mathrm{HH}$ are intrinsically epileptic}

Ictal EEG recordings from electrode contacts placed directly into $\mathrm{HH}$ tissue identify seizure onset within the lesion itself $[10,28,42]$. Direct stimulation of electrodes within $\mathrm{HH}$ can evoke typical gelastic seizures $[28,34]$.

\section{Roles of intrinsic neuron firing in seizure genesis}

In cortical dysplasia (CD), cytomegalic neurons (but not balloon cells) act as epileptic "pacemakers" and likely contribute to seizure genesis $[28,43,44]$. Electrophysiological microelectrode recordings have demonstrated that small $\mathrm{HH}$ neurons have intrinsic pacemakerlike firing behavior $[22,23,28,35,45]$ (Table 14).

\section{GABA-mediated excitation during normal development in epilepsy}

GABA is the most important inhibitory neurotransmitter in the CNS, exhibiting binding ligand-gated $\left(\mathrm{GABA}_{\mathrm{A}}\right.$ and $\left.\mathrm{GABA}_{\mathrm{C}}\right)$ and G-protein-coupled $\left(\mathrm{GABA}_{\mathrm{A}}\right.$ ) receptors. GABA $\mathrm{R}$ (receptor) is highly permeable to chloride ions, and its activation tends to hyperpolarize the membrane potential through the influx of these negative ions

\section{GABA shunt}

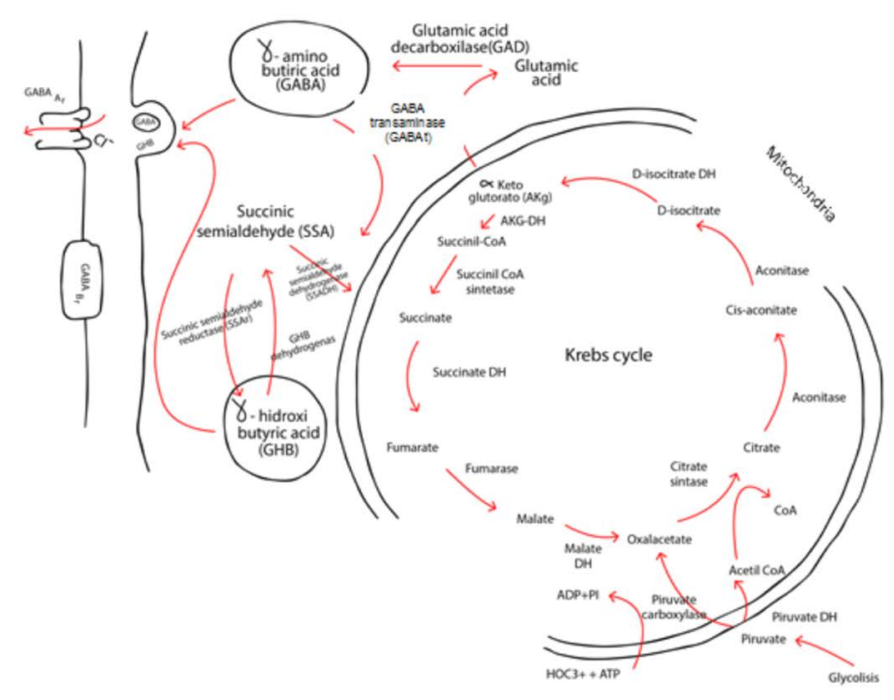

Figure 8. Glutamic acid decarboxylase (GAD) is an enzyme in charge of the metabolism of Glutamic acid to GABA. Here, we depict the relationship among the different enzymes associated to the production of neurotransmitters and the Krebs's cycle

Table 14. Comparison between small and large neurons in HH [ ${ }^{*}$ This activity was blocked by tetradotoxin (voltage dependent sodium channel blocker) but no change was seen with $\mathrm{GABA}_{\mathrm{A}}$ antagonist or inotropic glutamate receptor antagonist, suggesting intrinsic firing pacemaker]

\begin{tabular}{|c|c|c|}
\hline Neurotransmitter & Small neurons & Large neurons \\
\hline Soma size & $<16 \mu \mathrm{m}$ & Glutamic acid \\
\hline $\begin{array}{c}\text { Frequency of spontaneous } \\
\text { action potential (firing) }\end{array}$ & $10.5 \pm 0.8 \mathrm{~Hz}$ & Even quiescent at rest $(1 \mathrm{~Hz})$ \\
\hline $\begin{array}{c}\text { Resting membrane } \\
\text { potential }\end{array}$ & $-53.2 \pm 1.1 \mathrm{mV}$ & $-60.8 \pm 1.7 \mathrm{mV}$ \\
\hline Regular firing & $63 \%$ of neurons & -- \\
\hline Irregular firing & $28 \%$ of neurons & -- \\
\hline Burst firing & " $\%$ of neurons & -- \\
\hline
\end{tabular}


Maximiliano PN (2018) Hypothalamic hamartomas and Gelastic seizures. Chilean experience in a pediatric epilepsy surgery program during 13 years - Review of the literature

[28,46,47]. Deficits in $\mathrm{GABA}_{\mathrm{A}}$ receptor-mediated inhibition are a major mechanism contributing to seizure genesis in several forms of epilepsy $[28,48]$. In contrast to the hyperpolarizing (inhibitory) effect on normal mature neurons, GABA can exert an excitatory role on immature neurons $[28,49,50]$ (Figure 9).

If on these immature cells act a $\mathrm{GABA}_{\mathrm{A}}$ agonist, the $\mathrm{Cl}^{-}$levels inside the cell will increase and the reversal potential of $\mathrm{Cl}^{-}$will be caught soon favoring new excitation (Figure 10).

Ben Ari et al. reported that activation of GABA receptors on immature neurons in neonatal hippocampal slices induced membrane depolarization $[28,51]$. In these immature neurons, the reversal potential for $\mathrm{Cl}^{-}$was more positive than the resting membrane potential, suggesting that the intracellular $\mathrm{Cl}^{-}$concentration was higher in these neonatal neurons compared to mature neurons. GABA produces depolarization and increased concentration of intracellular calcium in immature neurons in a variety of brain regions including: hippocampus, neocortex and hypothalamus.

Notably, GABAergic excitation is also observed in several highly selected circumstances in normal mature neurons [28,50,52,53]. Functional alteration of $\mathrm{GABA}_{\mathrm{A}}$ receptors have demonstrated that this

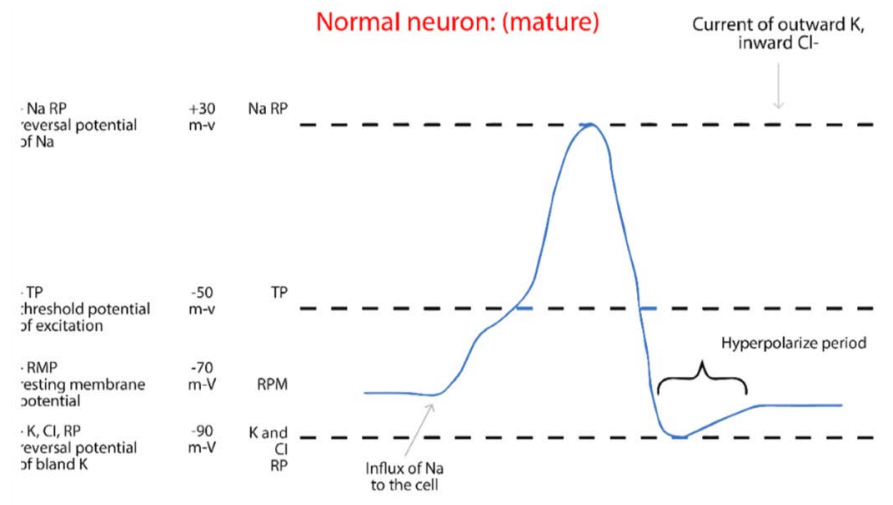

Immature neuron

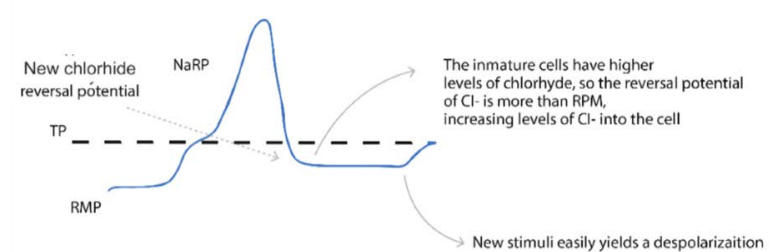

Figure 9. Comparison between a normal neuron and its action potential with an immature neuron, which has abnormalities in the phase 4 in action potential owing to the higher intracellular levels of chloride

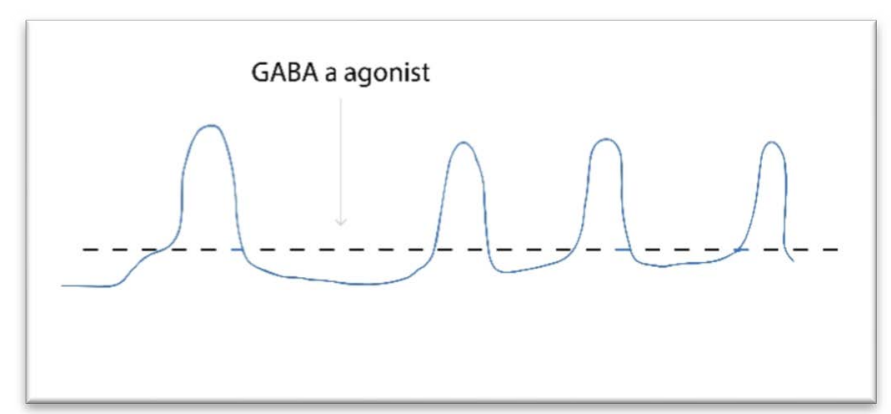

Figure 10. Mechanism through the cell could be transformed to potential excitable pacemaker functional switch can also been found in some epileptic conditions $[28,54]$.

Therefore, seizures appear to reduce the ability of neurons to prevent excess chloride accumulation, which in turns results in a quasipermanent accumulation of $\mathrm{Cl}^{-}$intracellulary, leading to the excitatory effects of GABA.

Role of $\mathrm{GABA}_{\mathrm{A}}$ receptor-mediated excitation in $\mathrm{HH}$ epileptogenesis

Most large $\mathrm{HH}$ neurons have a functionally immature response with depolarization and increased firing when exposed to GABA agonist $[22,28,36,45,50]$.

Wu et al. studied [28,45] the large and small $\mathrm{HH}$ neurons and muscimol was applied (selective GABA receptor agonist, responsible for psychotropic effects of the fungi Amanita muscaria) resulted in depolarization of $83 \%$ of large $\mathrm{HH}$ neurons and $24 \%$ of small neurons (Figure 11).

The functional difference between large and small $\mathrm{HH}$ neurons correlates with differences in intracellular chloride concentrations, consistent with reversal potential of $\mathrm{Cl}^{-}$in $\mathrm{HH}$ large neurons: Table 15 [28,45,55-57].

\section{Reasons of modified $\mathrm{Cl}^{-}$reversal potential}

1. Altered expression of the cation-chloride transporters NKCC1 and KCC2 $[28,34,46]$.

2. Reduced expression of KCC2 mRNA in large $\mathrm{HH}$ neurons.

3. Bumetanide (a NKCC1 inhibitor) partially blocks the depolarizing and firing behavior or large $\mathrm{HH}$ neurons exposed to GABA agonist $[22,28]$; so, there is an increasing of NKCC1 channels.

4. Constitutive activation of tyrosine kinase $\beta(\operatorname{tr} K \beta)$, also known as tropomyosin kinase receptor complex down streaming intracellular signaling pathways (Figure 12).

Seizures Onset: Figure 13.

Suppression of seizures: Figure 14.

\section{Mechanism responsible for increased synchrony}

There are 2 basic cellular conditions required for every epileptic network:

1. Imbalance of excitatory and inhibitory influences in the direction of net excitation.

2. Hyper synchrony of neuronal firing $[28,58]$

The contribution of synchronized firing of inhibitory neurons within the reticular nucleus as a fundamental contributing factor to generalized spike-wave discharges in the thalami-cortical circuit is well recognized [28,59]. $\mathrm{GABA}_{\mathrm{A}}$ receptor mediated synchronization also contributes to:

1. Seizure -onset mechanisms in focal epilepsy (including mesial temporal sclerosis $[28,60,61]$ and cortical dysplasia $[28,62]$.

2. Post-synaptic evidence for pacemaker-like GABA-firing as a contributing factor for epileptic network synchronization in cortical dysplasia $[28,63]$.

A possible contributing mechanism to GABA-mediated synchrony is the phenomenon of $G A B A_{A}$ current rundown, which is determined 


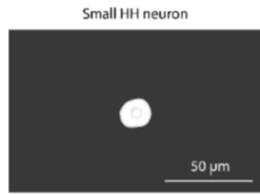

B
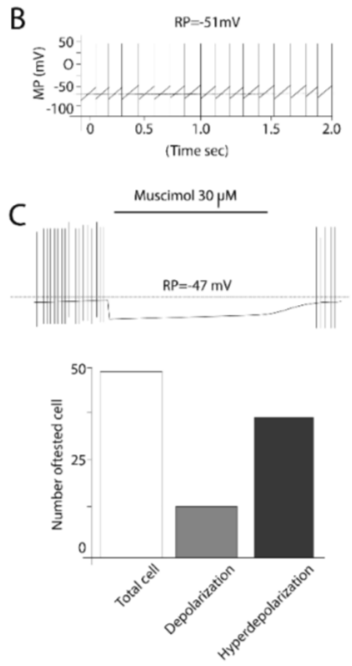

Figure 11. Activation of GABAa Rs differently modulates small and large HH neuron activity. Typical small (A left panel) and large (A right panel) from human HH tissues are depicted using phase contrast photo picture. Both types of $\mathrm{HH}$ neurons showed spontaneous AP firing but large cell had much lower firing rate (B) Gramicidin- performed patch-clamp recordings under current-clamp mode demonstrated that Muscimol hyperpolarized small (C left panel) but depolarized large (C right panel) HH neurons. (D) Summary of the numbers of small and large $\mathrm{HH}$ neurons and their responses to the GABAaR agonist muscimol using gramicidin-performed recordings. Taken from $\mathrm{Wu} \mathrm{J}$, et al. [31]

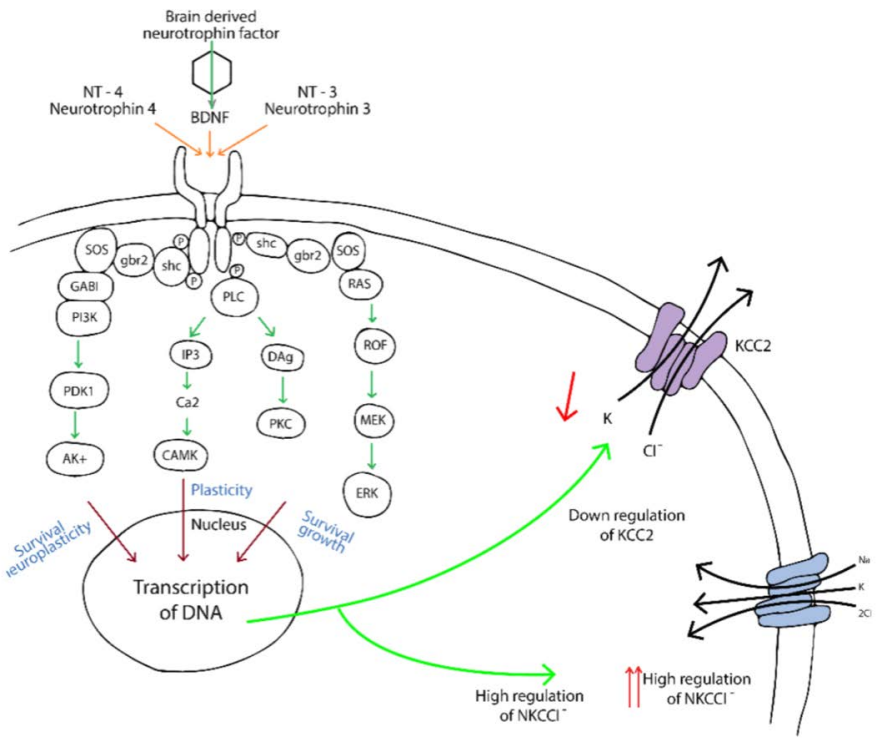

Figure 12. Scheme that depicts the tyrosin kinase B receptor (trkB) also named Tropomyosine kinase receptor, the stimulation of this kind of receptor by Neurotrophin-4 and 3 as well as Brain derived neurotrophin factor induces down regulation of $\mathrm{KCC} 2$, ending in diminishing potassium and chloride and increasing regulation of $\mathrm{NKCCl}$, all these thanks to the transcription of DNA favored by second messengers induced by the complex trk-B and its agonists

experimentally by observing decreasing trans membrane current responses to repetitive (use-dependent) GABA-ligand exposure and has been related to: temporal lobe epilepsy $[28,64,65]$ and cortical dysplasia $[28,66]$; furthermore, has been seen in surgically-resected $\mathrm{HH}$ tissue $[28,67]$.

The functional rundown was specific to GABA (It was not observed in response to repetitive exposure to glycine or glutamate) and was also specific to GABA receptors expressed on the surface of small $\mathrm{HH}$ neurons and not in large HH neurons [28,67].

Synchrony within small $\mathrm{HH}$ neuron clusters may also be enabled by non-synaptic mechanism $[28,68]$ : neuronal gap junctions (connexin 36) are highly expressed within small $\mathrm{HH}$ neuron clusters, and microelectrode field recordings of seizure-like discharges in surgically resected $\mathrm{HH}$ tissue slices are significantly reduced by pharmacologic exposure to gap junction blockers (Figure 15).

\section{Secondary epileptogenesis beyond the HH}

Since the 1990s, stereotactic intracerebral EEG and subsequent functional imaging studies in patients with epilepsy have demonstrated that $\mathrm{HH}$ is intrinsically epileptogenic $[10,15,22]$. However, multiple other seizure types were associated with ictal discharges affecting various neocortical areas but sparing the $\mathrm{HH}[10,15,17]$. Collectively,

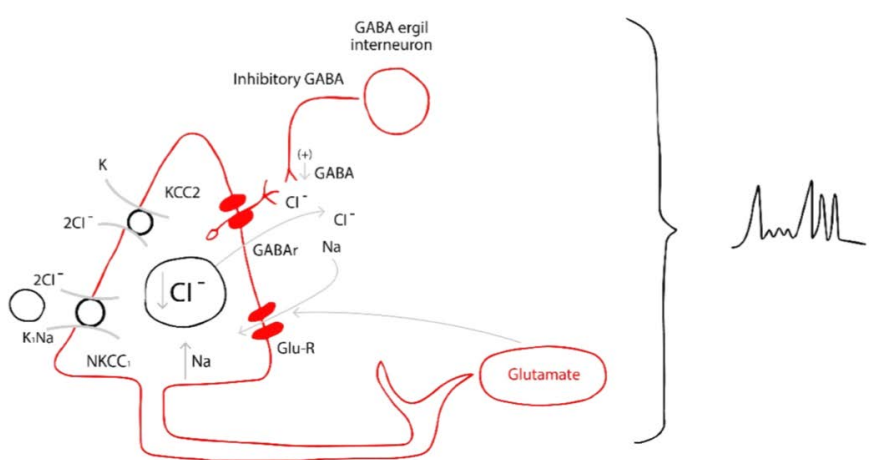

Figure 13. Intra and inter cellular pathophysiology of the seizures onset in $\mathrm{HH}$

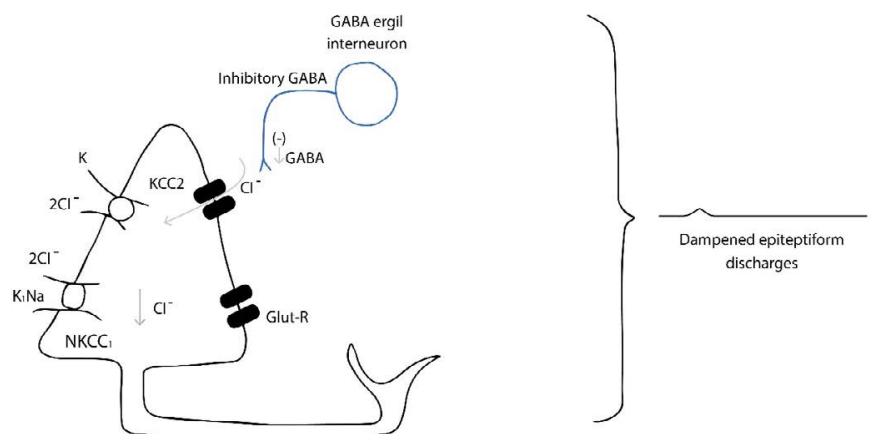

Figure 14. Mechanism of suppression seizures in $\mathrm{HH}$

Table 15. Large and small neurons: functional differences [ ${ }^{*}$ They were contributed for $\mathrm{HCO}_{3}^{-}$efflux and activation of L-type calcium channels $(31,71)$ and were blocked by bicuculline (competitive antagonist of $\mathrm{GABA}_{\mathrm{A}} \mathrm{R}$ similar to picrotoxine, which is no competitive antagonist of $\mathrm{GABA}_{\mathrm{A}}$ receptor. ${ }^{* *} \mathrm{They}$ have $\mathrm{Cl}^{-}$reversal similar o small $\mathrm{HH}$ neurons]

\begin{tabular}{|c|c|c|c|}
\hline & \multicolumn{2}{|c|}{ Large HH neurons } & Small HH neurons \\
\hline Cl- reversal potential $^{|c|}-36.2 \pm 1.5 \mathrm{mV}$ & $-59.4 \pm 3.9 \mathrm{mV}$ \\
\hline $\begin{array}{c}\text { Intracellular Cl- } \\
\text { concentration }\end{array}$ & \multicolumn{2}{|c|}{$39.1 \pm 2.8 \mathrm{mM}$} & $19.2 \pm 3.7 \mathrm{mM}$ \\
\hline Muscimol administration & $\begin{array}{c}\text { "Depolarizing } \\
70 \%\end{array}$ & $\begin{array}{c}\text { "** Hyperpolarizing } \\
30 \%\end{array}$ & $\begin{array}{c}\text { Hyperpolarizing } \\
100 \%\end{array}$ \\
\hline
\end{tabular}




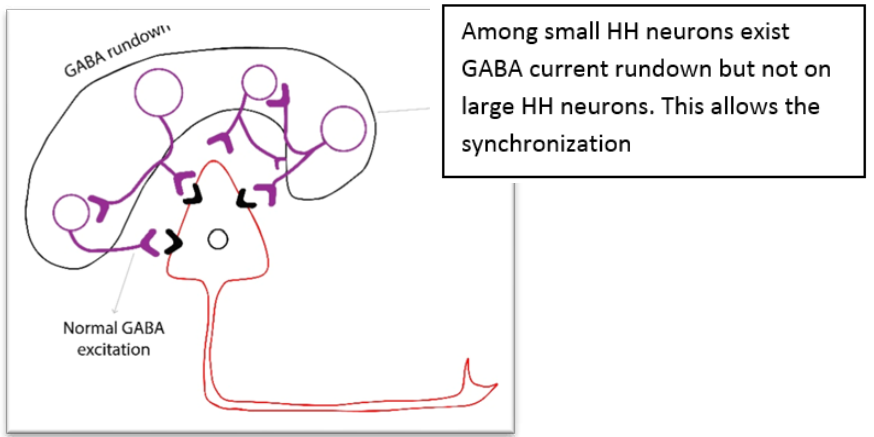

Figure 15. Mechanism of synchronization among small and large cells in $\mathrm{HH}$

these findings suggested the hypothesis of a secondary epileptogenesis as a possible underlying mechanism $[10,15,17,69]$.

Despite the inefficiency of procedures aimed at destroying/ inhibiting/disconnecting the $\mathrm{HH}$ in a non-negligible proportion of cases, "hamartoma-centrism" is generally the rule in the medical community.

Growing experience in epilepsy surgery addressing the $\mathrm{HH}$ showed that only (at best) $50 \%$ of the patients could be completely cured by the isolated treatment of the $\mathrm{HH}[15,70]$. A partial improvement is obtained in others, with persistence of electro-clinical seizure patterns suggesting neocortical involvement [15,71].

Secondary epileptogenesis could be defined as the induction of epileptic activities in the cellular elements of a previously normal neural network by interconnected actively discharging epileptogenic area $[15,72]$.

This process might be related to kindling $[15,73]$ which refers to the tendency of the brain to become progressively more epileptogenic when stimulated repeatedly at an intensity that initially is under the threshold for the generation of epileptic potential.

Morrel postulated three stages of secondary epileptogenesis [15]:

a) Stage 1: Dependent stage

Epileptogenic discharges detected in the secondary focus were driven by the primary focus $[15,74,75]$.

b) Stage 2: Intermediate stage

Independent inter ictal epileptiform discharges and later independent seizures were detected in the secondary focus. They initially persisted after removal of the primary focus, but eventually "ran down" and disappeared [15].

c) Sage 3: Independent stage

Epileptiform activity in the secondary epileptogenic area persisted after removal of the primary focus without running down [15].

Secondary epileptogenesis has been studied extensively in animals over the last 50 years, yet its existence and role in human epilepsy remain a controversial issue $[15,24,76]$. Some authors consider epilepsy associated with $\mathrm{HH}$ as a model of secondary epileptogenesis, at least for the first two stages $[15,70,77,78]$.

To date, there is no animal model for epilepsy with HH. Some common points could be discussed with the well-established model of audiogenic epilepsy in rodents [15,79]: during audiogenic kindling, epileptic discharge generated initially in the inferior colliculus, spreads from the brainstem to the forebrain and can progressively involve the hippocampus as well as widely distributed neocortical networks, finally leading to generalized tonic-clonic seizures $[15,80]$.

However, the projection pathways from the subcortically situated primary epileptogenic area toward the limbic circuit are probably quite different from those supposed to be implied in epilepsy with $\mathrm{HH}$.

Strictly speaking, hypothalamic-kindling phenomenon has been demonstrated in mice $[15,81]$. After-discharges could be induced in almost all regions of the hypothalamus, with a kindling rate similar to that of the amygdala, although the hypothalamus required a greater amount of stimulation before after-discharge threshold was reached.

In experimental animals, the time required to induce a secondary epileptic focus by kindling is known to increase across the species from amphibians to primates along with the rising complexity of the involved neural networks. Electrographic changes corresponding to a secondary focus occur within hours in the amphibian brain, within days to weeks in mice, within weeks to months in squirrel monkeys, and within months to years in macaques $[15,76,82]$.

The location of the secondary focus would be depending on the cortical-cortical connections and can occur in homologous contralateral cortex (mirror focus) or in a different, but connected region [15,82].

The kindling has been postulated as a cause of secondary epileptogenesis in $\mathrm{HH}$. To date, the direct clinical evidence for the independent stage of secondary epileptogenesis is lacking. However, it has been observed that additional seizure types often appeared with clear delay following the start of gelastic seizures during the clinical course $[15,42,44,83]$.

In the Strasbourg-Kork series of 15 patients explored for an $\mathrm{HH}$ $[15,84]$ dyscognitive seizures with electro-clinical features suggesting that temporal, frontal or parietal lobe involvement were documented in all but one case; however maturational changes may also explain the development of independent seizures [15].

The connectivity of hypothalamus with the ipsilateral thalamus, mainly with anterior nucleus (being relay to the anterior cingulate and limbic circuit) and dorso-medial thalamus (relay to orbitofrontal cortex, mesial premotor cortex, anterior cingulate) and the default mode network (precuneus and lateral inferior parietal lobe) [1], have been shown in ictal single photon emission computed tomography (SPECT) studies $[11,15,79,85]$.

Inter ictal hypometabolism of ipsilateral thalamus was demonstrated by 18 FDG-PET $[15,86]$.

Scalp and invasive recordings demonstrated an almost exclusive lateralization of neocortical interictal epileptiform discharges (IEDs) and intracranially recorded seizures ipsilaterally to the site of $\mathrm{HH}$ $[15,17]$.

The ultimate "proof of concept" for intrinsic epileptogenesis of $\mathrm{HH}$ is that its complete surgical resection (or treatment with other tissue-destructive therapeutic modalities) stops gelastic seizures $[15,84]$. Other seizure types can also disappear following $\mathrm{HH}$ removal, whereas isolated neocortical resection generally fail to control seizures $[15,69,87]$. Some studies have demonstrated that complete recovery from neocortical seizures could be delayed, occurring up to 6 months after $\mathrm{HH}$ ablation $[39,15]$. These data argue for the running-down phenomenon suggesting a reversal of secondary epileptogenesis at its second, intermediate stage as described by Morell [15,72].

A relationship between epilepsy duration and surgical outcome has been observed in some series $[15,31,88]$ : shorter duration of epilepsy 

the literature

seemed to be associated with better outcomes in the Strasbourg-Korj series:

- Less than 10 years of epilepsy before surgery $\rightarrow 80 \%$ achieved seizure free

- Between 11-20 years before surgery $\rightarrow 60 \%$ achieved seizure free

- More than 20 years before surgery $\rightarrow 20 \%$ achieved seizure free

According to the experience obtained by SEEG (stereotactic EEG), Munari et al. $[10,15]$ reported a detailed stereotactic exploration of a patient presenting with gelastic seizures and partial seizures suggestive of frontal involvement: gelastic seizures were linked to rapid discharges in the $\mathrm{HH}$, whereas tonic motor seizures were associated with a discharge extended to the hypothalamus and the cortical motor regions.

Mahone et al. [15,17] reported the complete Grenoble series (five cases) where gelastic or dacrystic seizures were correlated with discharges in the $\mathrm{HH}$, but other kinds of seizures were related to discharges affecting the neocortical regions.

They proposed that a large part of this kindling was related to the involvement of the cingulate gyrus $[15,79]$.

In Grenoble's experience, SEEG-guided radiofrequency thermoscoagulations were performed through the contacts located in the $\mathrm{HH}$ and led to a decrease of gelastic but not of tonic seizures.

\section{Diagnosis in $\mathrm{HH}$} 16):

The mechanisms for getting the suitable diagnostic work is (Table

a) Regarding the epilepsy symptoms:

- Routine scalp EEG monitoring

- Long term video EEG monitoring

- Ictal and interictal SPECT

- MRI

- Neuropsychological evaluation

- Ophthalmological assessment and perimetry

b) About the endocrine assessment

- Sex hormone

- Growth hormone levels

- Thyroid function

- Prolactin level

- Cortisol reserve with glucagon stimulation*

\section{Surgery}

Surgical resection for total removal of $\mathrm{HHs}$ has led to good seizure outcomes and behavioral improvement [1,89-91]

The different options of treatment for $\mathrm{HH}$ found in the literature are:

a) Surgery: "from above": trans-callosal, inter-fornicial approach (more

b) dangerous for the hypothalamus and fornix)

c) Endoscopic surgery: disconnection technique

d) Gamma knife surgery
Stereotactic radiofrequency thermos coagulation: disconnection technique

According to the Delalande and Fohlen classification, it is possible to recommend a specific therapeutic strategy depends on the localization of the tumor: Figure 16.

\section{Endoscopic procedure for $\mathrm{HH}$}

For the endoscopic surgical treatment of $\mathrm{HH}$ a $3.8 \mathrm{~mm}$ outside diameter neuroendoscope is advisable. The procedure is performed through Kocher's point.

Once the telescope has been advanced through the foramen of Monroe, the $\mathrm{HH}$ protruding from the floor and the lateral wall of the third ventricle is seen; it is easily defined the place where the $\mathrm{HH}$ is attached, however for difficult cases, the depth electrode inserted prior to endoscope surgery to guide the depth and the margin of disconnection is useful.

The disconnection will begin at the border between the $\mathrm{HH}$ and the mammillary body and proceed along the midline postero-inferior floor of the third ventricle. The direction of resection is from posterior to anterior and from lateral to inferior midline.

Neuronavigation endoscopy may be a very useful help to guide the resection.

\section{Discussion}

Usually, patients with $\mathrm{HH}$ suffered of refractory epilepsy and the frequency of seizures / month are high. Few cases debuted with Gelastic seizures (14\%), nonetheless, with the maturation of the epileptogenic zone as well as the epileptic networks, the patients were increasing the number of GS with the time (being the $42 \%$ of the seizures before surgery). Other kind of seizures seen in $\mathrm{HH}$ are focal motor, focal temporal and generalized.

Commonly the patients with $\mathrm{HH}$ have other neurological symptoms such as behavioral disorders, endocrinological disturbances and visual impairment.

Mental retardation is common in patients older than 5 years in $\mathrm{HH}$, there is also a delay in neurological development in younger ages.

In our experience most of the $\mathrm{HH}$ had wide implantation inside the third ventricle. We did not find difference in the frequency of seizures or electrophysiological findings respect to the side.

Only $14 \%$ of the patients had a normal preoperative baseline EEG, and most had a slow rhythm with theta waves, lateralizing to the same side of the lesion; commonly ictal findings were: spikes, poli spikes and spike- slow wave.

Table 16. Role of the Glucagon stimulation testing

"Glucagon stimulation testing [30]

- The $\alpha$-cell of the Langerhans Island in the pancreas normally produces glucagon. It induces the gluconeogenesis by reduction of fructose 2,6 diphosphate. Glucagon increases the level of glucose leading to augmentation of insulin levels, the latter carry to decreasing of the level of glucagon

- This test has been used more commonly for growth hormone deficiency (GHD).

- It is not well known how glucagon induces ACTH and thus increases cortisol levels.

- Glucagon $(0.1 \mathrm{mg} / \mathrm{kg})$, only by intramuscular or subcutaneous application (not intravenous), induces release of GH, ACTH. Seeming this is caused by glucagon activity directly on the hypophysis and increasing activity on $\alpha$ receptors.

- It is also used for evaluating pancreatic reserve (insulin reserve): deficit of GH, reserve of ACTH. 


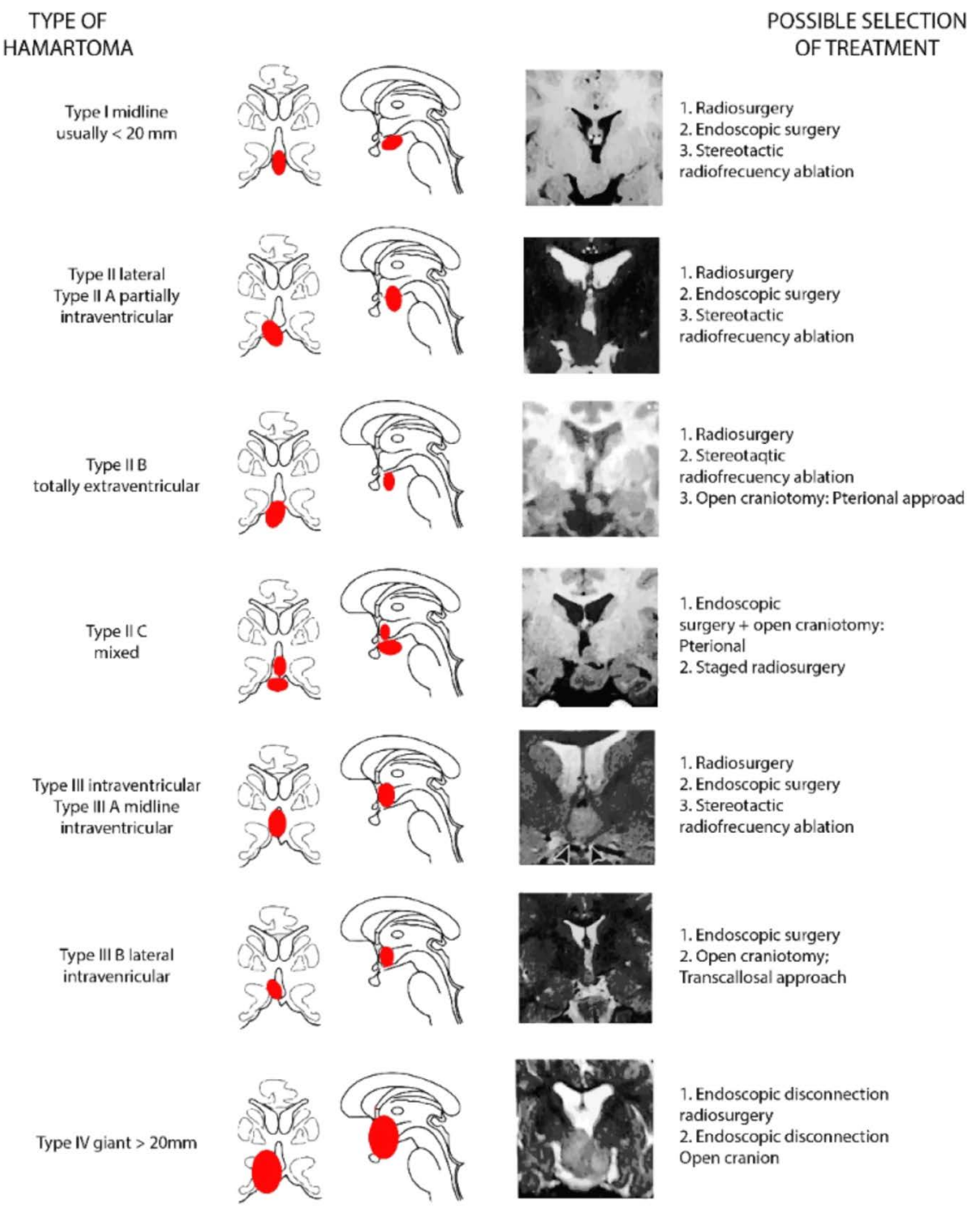

Figure 16. Classification of the $\mathrm{HH}$ according to the volume and the implantation. A large Hamartoma ( $>20 \mathrm{~mm})$ is defined as a giant $\mathrm{HH}$ (Type IV). Small $\mathrm{HHs}(<20 \mathrm{~mm})$ are classified as midline Type I and lateral Type II and intraventricular (Type III) according to their location relative to the third ventricle. Taken from Delalande O, et al. [28]

The EEG was able to lateralize correctly in $86 \%$ of the cases

All patients were operated with open surgery using trans-callosal or trans-silvian approach, indistinctly of the technique only one patient had a total resection.

The most common complication was the third nerve palsy. The stay in ICU was short (mode of 2 days).

$86 \%$ of the patients after surgery experienced improvement in the frequency of seizures (Engel I, II and III) from this proportion $42.85 \%$ were Engel I; only $14 \%$ of the patients worsened. (Engel IV).

The size of the $\mathrm{HH}$ was not an important factor in the result (one patient with large volume of the lesion resulted with Engel Ia and the another one with similar volume had an outcome defined as IIIc). This finding requires to be analyzed deeper in future studies.

The patient's epilepsy was partially controlled but was not possible to reduce the AEDs; probably because the partial resection performed, allowed some kind of disconnection. Notwithstanding of great resection performed or the type of approach, we did not find a deterioration in mental development after surgery.

\section{Conclusions}

The pre-surgical condition of the patients has the same features respect to the description in the global literature. It was interesting that only $14 \%$ of our patients presented with gelastic seizures. However, with the time, near to $42 \%$ had them, possibly secondary to the maturation of the epileptogenic zone and network. The experience in our institution about $\mathrm{HH}$ and epilepsy refractory to medical treatment is particularly using open surgery. In spite of the open technique used, the possibility to remove the totality of the tumor was only $14 \%$. Nonetheless the results according to the international parameters (ILAE's and Engel's outcome score) for evaluating the successful is acceptable, possibly because the surgery finishes disconnecting the hamartoma from the rest of the hypothalamus. The $84 \%$ are classified with improvement after surgery and $42.85 \%$ are currently without seizures. We did not have behavioral complications or changes in the neuropsychological evaluation after surgery. Respect to the impact of the surgery on the number of medications or doses used of AEDs, only $29 \%$ was possible to reduce them, no one could discontinue the medication, even $57 \%$ had to increase the AEDs. We believe the patients became with the surgery 
Maximiliano PN (2018) Hypothalamic hamartomas and Gelastic seizures. Chilean experience in a pediatric epilepsy surgery program during 13 years - Review of the literature

"AEDs sensitive", possibly due to the mass reduction. We hypothesized that partial removal of the tumor reduces the charge of the smallest neurons implicated in the synchronization on the large neurons. It should be noted that patients in whom seizures did not subside with the surgical treatment were treated with benzodiazepines, drugs that act at the level of chlorine channels

\section{Conflict of interest}

None.

\section{References}

1. Shim KW, Park EK, Kim DS (2017) Endoscopic Treatment of Hypothalamic Hamartomas. J Korean Neurosurg Soc 60: 294-300. [Crossref]

2. Arroyo S, Santamaria J, Sanmarti F, Lomena F, Catafau A, et al. (1997) Ictal laughter associated with paroxysmal hypothalamopituitary dysfunction. Epilepsia 38: 114-117. [Crossref]

3. Cerullo A, Tinuper P, Provini F, Contin M, Rosati A, et al. (1998) Autonomic and hormonal ictal changes in gelastic seizures from hypothalamic hamartomas. Electroencephalogr Clin Neurophysiol 107: 317- 322. [Crossref]

4. Boyko OB, Curnes JT, Oakes WJ, Burger PC (1991) Hamartomas of the tuber cinereum: CT, MR, and pathologic findings. AJNR Am J Neuroradiol 12: 309-314. [Crossref]

5. Arita K, Ikawa F, Kurisu K, Sumida M, Harada K, et al. (1999) The relationship between magnetic resonance imaging findings and clinical manifestations of hypothalamic hamartoma. J Neurosurg 91: 212-220. [Crossref]

6. Gascon GG, Lombroso CT (1971) Epileptic (gelastic) laughter. Epilepsia 12: 63-76. [Crossref]

7. Gumpert J, Hansotia P, Upton A (1970) Gelastic epilepsy. J Neurol Neurosurg Psychiatry 33: 479-483. [Crossref]

8. Berkovic SF, Arzimanoglou A, Kuzniecky R, Harvey AS, Palmini A, et al. (2003) Hypothalamic hamartoma and seizures: a treatable epileptic encephalopathy. Epilepsia 44: 969-973. [Crossref]

9. Likavec AM, Dickerman RD, Heiss JD, Liow K (2000) Retrospective analysis of surgical treatment outcomes for gelastic seizures: a review of the literature. Seizure 9: 204-207. [Crossref]

10. Munari C, Kahane P, Francione S, Hoffmann D, Tassi L, et al. (1995) Role of the hypothalamic hamartoma in the genesis of gelastic fits (a video-stereo-EEG study). Electroencephalogr Clin Neurophysiol 95: 154-160. [Crossref]

11. Kameyama S, Masuda H, Murakami H (2010) Ictogenesis and symptomatogenesis of gelastic seizures in hypothalamic hamartomas: an ictal SPECT study. Epilepsia 51: 2270-2279. [Crossref]

12. Khan S, Wright I, Javed S, Sharples P, Jardine P, et al. (2009) High frequency stimulation of the mamillothalamic tract for the treatment of resistant seizures associated with hypothalamic hamartoma. Epilepsia 50: 1608-1611. [Crossref]

13. Usami K, Matsumoto R, Sawamoto N, Murakami H, Inouchi M, et al. (2016) Epileptic network of hypothalamic hamartoma: An EEG-fMRI study. Epilepsy Res 125: 1-9. [Crossref]

14. Troester M, Haine-Schlagel R, Ng YT, Chapman K, Chung S, et al. (2011) EEG and video-EEG seizure monitoring has limited utility in patients with hypothalamic hamartoma and epilepsy. Epilepsia 52: 1137-1143. [Crossref]

15. Scholly J, Staack AM, Kahane P, Scavarda D, Régis J, et al. (2017) Hypothalamic hamartoma: Epileptogenesis beyond the lesion? Epilepsia 58 Suppl 2: 32-40. [Crossref]

16. DiFazio MP, Davis RG (2000) Utility of early single photon emission computed tomography (SPECT) in neonatal gelastic epilepsy associated with hypothalamic hamartoma. J Child Neurol 15: 414-417. [Crossref]

17. Kahane P, Ryvlin P, Hoffmann D, Minotti L, Benabid AL (2003) From hypothalamic hamartoma to cortex: what can be learnt from depth recordings and stimulation? Epileptic Disord 5: 205-217. [Crossref]

18. Shim KW, Chang JH, Park YG, Kim HD, Choi JU, et al. (2008) Treatment modality for intractable epilepsy in hypothalamic hamartomatous lesions. Neurosurgery 62: 847856. [Crossref]

19. Specchio N, Rizzi M, Trivisano M, Fusco L, Rebessi E, et al. (2015) Acute intralesional recording in hypothalamic hamartoma: description of 4 cases. Acta Neurol Belg 115 : 233-239. [Crossref]
20. Beggs J, Nakada S, Fenoglio K, Wu J, Coons S, et al. (2008) Hypothalamic hamartomas associated with epilepsy: ultrastructural features. J Neuropathol Exp Neurol 67: 657668. [Crossref]

21. Coons SW, Rekate HL, Prenger EC, Wang N, Drees C, et al. (2007) The histopathology of hypothalamic hamartomas: study of 57 cases. J Neuropathol Exp Neurol 66: 131141. [Crossref]

22. Kim do Y, Fenoglio KA, Simeone TA, Coons SW, Wu J, et al. (2008) GABAA receptormediated activation of L-type calcium channels induces neuronal excitation in surgically resected human hypothalamic hamartomas. Epilepsia 49: 861-871. [Crossref]

23. Wu J, Xu L, Kim DY, Rho JM, St John PA, et al. (2005) Electrophysiological properties of human hypothalamic hamartomas. Ann Neurol 58: 371-382. [Crossref]

24. Steinmetz PN, Wait SD, Lekovic GP, Rekate HL, Kerrigan JF (2013) Firing behavior and network activity of single neurons in human epileptic hypothalamic hamartoma. Front Neurol 4: 210. [Crossref]

25. Roberts CM, Thompson EM, Selden NR (2011) Transendoscopic intraoperative recording of gelastic seizures from a hypothalamic hamartoma. Pediatr Neurosurg 47 147-151. [Crossref]

26. Striano S, Striano P, Cirillo S, Nocerino C, Bilo L, et al. (2002) Small hypothalamic hamartomas and gelastic seizures. Epileptic Disord 4: 129-133. [Crossref]

27. Valdueza JM, Cristante L, Dammann O, Bentele K, Vortmeyer A, et al. (1994) Hypothalamic hamartomas: with special reference to gelastic epilepsy and surgery. Neurosurgery 34: 949-958. [Crossref]

28. Wu J, Gao M, Shen JX, Qiu S, Kerrigan J (2015) Mechanisms of intrinsic epileptogenesis in human gelastic seizures with hypothalamic hamartoma. CNS Neurosci Ther 21: 104 111. [Crossref]

29. Berkovic SF, Andermann F, Melanson D, Ethier RE, Feindel W, et al. (1988) Hypothalamic hamartomas and ictal laughter: Evolution of a characteristic epileptic syndrome and diagnostic value of magnetic resonance imaging. Ann Neurol 23: 429439.

30. Choi JU, Kim DS (2012) Treatment modalities for intractable epilepsy in hypothalamic hamartoma. Adv Tech Stand Neurosurg 39: 117-130. [Crossref]

31. Ng YT, Rekate HL, Prenger EC, Chung SS, Feiz-Erfan I, et al. (2006) Transcallosa resection of hypothalamic hamartoma for intractable epilepsy. Epilepsia 47: 11921202. [Crossref]

32. Berkovic SF, Kuzniecky RI, Andermann F (1997) Human epileptogenesis and hypothalamic hamartomas: New lessons from an experiment of nature. Epilepsia 38: $1-3$.

33. Striano S, Meo R, Bilo L, Cirillo S, Nocerino C, et al. (1999) Gelastic epilepsy: symptomatic and cryptogenic cases. Epilepsia 40: 294-302. [Crossref]

34. Kuzniecky R, Guthrie B, Mountz J, Bebin M, Faught E, et al. (1997) Intrinsic epileptogenesis of hypothalamic hamartomas in gelastic epilepsy. Ann Neurol 42: 6067. [Crossref]

35. Wu J, Chang Y, Li G, Xue F, DeChon J et al. (2007) Electrophysiological properties and subunit composition of GABAA receptors in patients with gelastic seizures and hypothalamic hamartoma. J Neurophysiol 98: 5-15. [Crossref]

36. Freeman JL, Harvey AS, Rosenfeld JV, Wrennall JA, Bailey CA, et al. (2003) Generalized epilepsy in hypothalamic hamartoma: Evolution and postoperative resolution. Neurology 60: 762-767. [Crossref]

37. Castro LH, Ferreira LK, Teles LR, Jorge CL, Arantes PR, et al. (2007) Epilepsy syndromes associated with hypothalamic hamartoma. Seizure 16: 50-58. [Crossref]

38. Parvizi J, Le S, Foster B, Bourgeois B, Riviello JJ, et al. (2011) Gelastic epilepsy and hypothalamic hamartomas: Neuroanatomical analysis of brain lesions in 100 patients. Brain 134: 2960-2968. [Crossref]

39. Sturm JW, Andermann F, Berkovic SF (2000) "Pressure to laugh": An unusual epileptic syndrome associated with small hypothalamic hamartomas. Neurology 54: 971-973. [Crossref]

40. Striano S, Striano P, Sarappa C, Boccella P (2005) The clinical spectrum and natural history of gelastic epilepsy-hypothalamic hamartoma syndrome. Seizure 14: 232-239. [Crossref]

41. Sato M, Ushio Y, Arita N, Mogami H (1985) Hypothalamic hamartoma: report of two cases. Neurosurgery 16: 198-206. [Crossref]

42. Palmini A, Chandler C, Andermann F, Costa Da Costa J, Paglioli-Neto E, et al. (2002) Resection of the lesion in patients with hypothalamic hamartomas and catastrophic epilepsy. Neurology 58: 1338-1347. [Crossref] 
Maximiliano PN (2018) Hypothalamic hamartomas and Gelastic seizures. Chilean experience in a pediatric epilepsy surgery program during 13 years - Review of the literature

43. Cepeda C, Andre VM, Levine MS, Salamon N, Miyata H, et al. (2006) Epileptogenesis in pediatric cortical dysplasia: The dysmature cerebral developmental hypothesis. Epilepsy Behav 9: 219-235. [Crossref]

44. Cepeda C, André VM, Wu N, Yamazaki I, Uzgil B, et al. (2007) Immature neurons and GABA networks may contribute to epileptogenesis in pediatric cortical dysplasia. Epilepsia 48 Suppl 5: 79-85. [Crossref]

45. Wu J, DeChon J, Xue F, Li G, Ellsworth K, et al. (2008) GABAA receptor-mediated excitation in dissociated neurons from human hypothalamic hamartomas. Exp Neurol 213: 397-404. [Crossref]

46. Macdonald RL, Olsen RW (1994) GABAA receptor channels. Annu Rev Neurosci 17: 569-602. [Crossref]

47. Farrant M, Nusser Z (2005) Variations on an inhibitory theme: phasic and tonic activation of GABA(A) receptors. Nat Rev Neurosci 6: 215-229. [Crossref]

48. Benarroch EE (2007) GABAA receptor heterogeneity, function, and implications for epilepsy. Neurology 68: 612-614. [Crossref]

49. Ben-Ari Y (2002) Excitatory actions of gaba during development: the nature of the nurture. Nat Rev Neurosci 3: 728-739. [Crossref]

50. Stein V, Nicoll RA (2003) GABA generates excitement. Neuron 37: 375-378. [Crossref]

51. Ben-Ari Y, Cherubini E, Corradetti R, Gaiarsa JL (1989) Giant synaptic potentials in immature rat CA3 hippocampal neurones. J Physiol 416: 303-325. [Crossref]

52. Kim DY, Fenoglio KA, Kerrigan JF, Rho JM (2009) Bicarbonate contributes to GABAA receptor-mediated neuronal excitation in surgically resected human hypothalamic hamartomas. Epilepsy Res 83: 89-93. [Crossref]

53. Moenter SM, DeFazio RA (2005) Endogenous gamma-aminobutyric acid can excite gonadotropin-releasing hormone neurons. Endocrinology 146: 5374-5379. [Crossref]

54. Cohen I, Navarro V, Clemenceau S, Baulac M, Miles R (2002) On the origin of interictal activity in human temporal lobe epilepsy in vitro. Science 298: 1418-1421. [Crossref]

55. Cossart R, Bernard C, Ben-Ari Y (2005) Multiple facets of GABAergic neurons and synapses: Multiple fates of GABA signalling in epilepsies. Trends Neurosci 28: 108115. [Crossref]

56. Khalilov I, Holmes GL, Ben-Ari Y (2003) In vitro formation of a secondary epileptogenic mirror focus by interhippocampal propagation of seizures. Nat Neurosci 6: 1079-1085. [Crossref]

57. Andermann F, Arzimanoglou A, Berkovic SF (2003) Hypothalamic hamartoma and epilepsy: the pathway of discovery. Epileptic Disord 5: 173-175. [Crossref]

58. Prince DA (1985) Physiological mechanisms of focal epileptogenesis. Epilepsia 26 Suppl 1: S3-14. [Crossref]

59. Huguenard JR, McCormick DA (2007) Thalamic synchrony and dynamic regulation of global forebrain oscillations. Trends Neurosci 30: 350-356. [Crossref]

60. Kohling R, Vreugdenhil M, Bracci E, Jeffreys JGR (2000) Ictal epileptiform activity is facilitated by hippocampal GABAA receptor-mediated oscillations. J Neurosci 20 : 6820-6829. [Crossref]

61. Behr C, D'Antuono M, Hamidi S, Herrington R, Lévesque M, et al. (2014) Limbic networks and epileptiform synchronization: the view from the experimental side. Int Rev Neurobiol 114: 63-87. [Crossref]

62. D'Antuono M, Louvel J, Kohling R, et al. (2004) GABAA receptormediated synchronization leads to ictogenesis in the human dysplastic cortex. Brain 127: 16261640. [Crossref]

63. Cepeda C, Chen JY, Wu JY, Fisher RS, Vinters HV, et al. (2014) Pacemaker GABA synaptic activity may contribute to network synchronization in pediatric cortical dysplasia. Neurobiol Dis 62: 208-217. [Crossref]

64. Palma E, Roseti C, Maiolino F, Fucile S, Martinello K, et al. (2007) GABA(A)-current rundown of temporal lobe epilepsy is associated with repetitive activation of GABA(A) "phasic" receptors. Proc Natl Acad Sci U S A 104: 20944-20948. [Crossref]

65. Cifelli P, Palma E, Roseti C, Verlengia G, Simonato M (2013) Changes in the sensitivity of GABAA current rundown to drug treatments in a model of temporal lobe epilepsy. Front Cell Neurosci 7: 108. [Crossref]

66. Jansen LA, Peugh LD, Ojemann JG (2008) GABAA receptor properties in catastrophic infantile epilepsy. Epilepsy Res 81: 188-197. [Crossref]

67. Li G, Yang K, Zheng C, Liu Q, Chang Y, et al. (2011) Functional rundown of gammaaminobutyric acid(A) receptors in human hypothalamic hamartomas. Ann Neurol 69: 664-672. [Crossref]

68. Dudek FE, Yasumura T, Rash JE (1998) 'Non-synaptic' mechanisms in seizures and epileptogenesis. Cell Biol Int 22: 793-805. [Crossref]
69. Kerrigan JF, Ng YT, Chung S, Rekate HL (2005) The hypothalamic hamartoma: a model of subcortical epileptogenesis and encephalopathy. Semin Pediatr Neurol 12 119-131. [Crossref]

70. Kerrigan JF (2011) Hypothalamic hamartoma and gelastic epilepsy. In Shorvon SD, Andermann F, Guerrini R (Eds) The causes of Epilepsy. Cambridge: Cambridge University Press, pp: 449-453.

71. Régis J, Carron R, Bartolomei F, Chauvel P (2012) Seeking new paradigms in epilepsy: stereotactic radiosurgery. Clin Neurosurg 59: 59-69. [Crossref]

72. Morrell F (1985) Secondary epileptogenesis in man. Arch Neurol 42: 318-335. [Crossref]

73. Goddard GV (1967) Development of epileptic seizures through brain stimulation at low intensity. Nature 214: 1020-1021. [Crossref]

74. Morrell F, Roberts L, Jasper HH (1956) Effect of focal epileptogenic lesions and their ablation upon conditioned electrical responses of the brain in the monkey. Electroencephalogr Clin Neurophysiol 8: 217-236. [Crossref]

75. Morrell F, deToledo-Morrell L (1999) From mirror focus to secondary epileptogenesis in man: an historical review. Adv Neurol 81: 11-23. [Crossref]

76. Wilder BJ, Morrell F (1967) Secondary epileptogenesis in the frog forebrain. Neurology 17: 1041-1051. [Crossref]

77. Norden AD, Blumenfeld H (2002) The role of subcortical structures in human epilepsy. Epilepsy Behav 3: 219-231. [Crossref]

78. Valentin A, Lazaro M, Mullatti N, Cervantes S, Malik I, et al. (2011) Cingulate epileptogenesis in hypothalamic hamartoma. Epilepsia 52: e35-39. [Crossref]

79. Marescaux C, Vergnes M, Kiesmann M, Depaulis A, Micheletti G, et al. (1987) Kindling of audiogenic seizures in Wistar rats: an EEG study. Exp Neurol 97: 160-168. [Crossref]

80. Hirsch E, Maton B, Vergnes M, Depaulis A, Marescaux C (1992) Positive transfer of audiogenic kindling to electrical hippocampal kindling in rats. Epilepsy Res 11: 159166. [Crossref]

81. Cullen N, Goddard GV (1975) Kindling in the hypothalamus and transfer to the ipsilateral amygdala. Behav Biol 15: 119-131. [Crossref]

82. Cibula JE, Gilmore RL (1997) Secondary epileptogenesis in humans. J Clin Neurophysiol 14: 111-127. [Crossref]

83. Striano S, Santulli L, Ianniciello M, Ferretti M, Romanelli P, et al. (2012) The gelastic seizureshypothalamic hamartoma syndrome: facts, hypotheses, and perspectives. Epilepsy Behav 24: 7-13. [Crossref]

84. Scholly J, Valenti MP, Staack AM, Strobl K, Bast T, et al. (2013) Hypothalamic hamartoma: is the epileptogenic zone always hypothalamic? Arguments for independen (third stage) secondary epileptogenesis. Epilepsia 54: 123-128. [Crossref]

85. Arroyo S, Lesser RP, Gordon B, Uematsu S, Hart J, et al. (1993) Mirth, laughter and gelastic seizures. Brain 116: 757-780. [Crossref]

86. Ryvlin P, Ravier C, Bouvard S, Mauguire F, Le Bars D, et al. (2003) Positron emission tomography in epileptogenic hypothalamic hamartomas. Epileptic Disord 5: 219-227. [Crossref]

87. Cascino GD, Andermann F, Berkovic SF, Kuzniecky RI, Sharbrough FW, et al. (1993) Gelastic seizures and hypothalamic hamartomas: evaluation of patients undergoing chronic intracranial EEG monitoring and outcome of surgical treatment. Neurology 43 : 747-750. [Crossref]

88. Schulze-Bonhage A1, Trippel M, Wagner K, Bast T, Deimling FV, et al. (2008) Outcome and predictors of interstitial radiosurgery in the treatment of gelastic epilepsy. Neurology 71: 277-282. [Crossref]

89. Delalande O, Fohlen M (2003) Disconnecting surgical treatment of hypothalamic hamartoma in children and adults with refractory epilepsy and proposal of a new classification. Neurol Med Chir (Tokyo) 43: 61-68. [Crossref]

90. Rosenfeld JV, Freeman JL, Harvey AS (2004) Operative technique: the anterior transcallosal transseptal interforniceal approach to the third ventricle and resection of hypothalamic hamartomas. J Clin Neurosci 11: 738-744. [Crossref]

91. Yuen KC (2011) Glucagon stimulation testing in assessing for adult growth hormone deficiency: current stats and future perspectives. ISRN Endocrinol 2011: 608056 [Crossref]

Copyright: (C2018 Maximiliano PN. This is an open-access article distributed under the terms of the Creative Commons Attribution License, which permits unrestricted use, distribution, and reproduction in any medium, provided the original author and source are credited. 